\title{
NICTでのSr光格子時計開発とクロックレーザー用新型光共振器の設計
}

\author{
井戸哲也，山口 敦史，小出 美知 \\ (独)情報通信研究機構 光・時空標準グループ ( ⿳184-8795 東京都小金井市貫井北町4-2-1)
}

\section{A Sr Lattice Clock at NICT and A Design of An Optical Cavity to Stabilize Clock Lasers}

\author{
Tetsuya IDO, Atsushi YAMAGUCHI, and Michi KOIDE \\ Space-Time Standards Group, National Institute of Information and Communications Technology, \\ 4-2-1 Nukui-kitamachi, Koganei, Tokyo 184-8795
}

(Received February 25, 2010)

\begin{abstract}
An ${ }^{87} \mathrm{Sr}$ lattice clock has begun to work in NICT (National Institute of Information and Communications Technology). The obtained spectral width of high resolution spectroscopy was $1.2 \mathrm{kHz}$ (full-width-halfmaximum) and absolute frequency agreed with the frequency recommended by CIPM. In addition, a novel design of rather long high-finesse optical cavities to stabilize clock lasers is proposed. The variation of cavity length caused by vibrations was reduced by optimizing various dimensions of the cavity, resulting in the projected vibration immunity in the same level as state-of-the-art $10 \mathrm{~cm}$ cavities.
\end{abstract}

Key Words: Optical frequency standard, Lattice clock, Clock laser, Optical cavity, Laser stabilization

\section{1. 歴史的転換点にある周波数標準}

科学技術のひとつの目的は自然をある程度制御・利用 することによって我々の生活水準を上げることにある。 これを実現するための第一歩はまず自然の状態を知るこ とであるが，その際には状態を定量的に把握することが 肝要である. 定量的に状態を把握する作業がいわゆる計 測であるが，次元のある物理量を測定する場合通常行っ ている作業は計測される量と, 既知の信頼できる量との 比率を出しているに過ぎない. この測定の基礎となって いる既知の信頼できる量を供給する技術こそが「標準」技 術であり，科学技術の大きな基礎を形成している.

周波数標準は通常孤立原子の量子遷移の共鳴周波数に 求められるが, 得られる精度が他の物理標準に比べて圧 倒的に高いため, 多数の物理標準や精密計測は測定量を 時間に変換することによって精度を実現している。そし てこの標準の中の標準とも言われる周波数標準は実は現 在歴史的な転換点にさしかかっている．現在の時間標準 である“1秒” はセシウム原子の基底状態における超微細 構造準位間の共鳴周波数によって1967年に定義され，そ れ以来周波数標準の確度は年々向上し，90年代には原子 泉方式を利用することによって大きく進歩して現在では $4 \times 10^{-16}$ に到達している。 しかし, この確度は時計の動 作を 10 日間以上に渡って行いその平均を取ることによっ てようやく得られるため, 現状のまま確度を改善するに は系統誤差の評価等に膨大な測定時間が必要になる。ま
た原子数の増加もしくは飛行時間の延長で安定度を上げ て測定時間を短縮する試みについても大きな衝突シフト による確度の劣化を伴うために最終的な確度の改善にな かなか寄与しないのが現状である。一方でこの状態を予 見して，周波数がより高い原子の光学遷移にその標準を 求める研究がレーザーの発明時より精力的に行われてき ており,さらには前世紀末の光周波数コムの発明により 光学遷移においてその周波数を現行のCsによる定義に 基づいて計測することが可能となり，新たに光学遷移に て国際単位系の1秒を再定義する際の過去との連続性が 担保された。そして今世紀に入りついにCs原子泉時計 を超える光時計が現実の物となり, 秒の再定義が時刻周 波数標準の研究者の間で真剣に議論されつつある. 光領 域での秒の再定義についての議論は, 一般にはCsでな くどんな原子もしくはイオンを利用するのか, という話 題になる傾向にある。しかし，その際には新たな高性能 標準による利益を享受するには同時に周辺技術の改善も 強く要請されることを頭に置きたい，具体的な関連技術 としては，雑音を付加することなく光からマイクロ波に 周波数変換する技術, 離れた 2 点間の時計の周波数を比 較する技術等である。とりわけ周波数を比較する技術は 標準開発の本質を表している。通常我々が計測する場合 は非測定物よりも安定なものさしで測定するが，最も性 能が高いものさしの性能を測定する場合には，より安定 なものさしは存在しないため, 我々に出来る最善の手段 は同一性能のものさしでお互いの相対的な関係を測定し 
てその信頼性を確認することであり，これこそが比較な のである.

さて, 話を戻して, Csの超微細構造間のマイクロ波 遷移の代わりにどの光学遷移を利用するか, という観点 では現在イオン時計と中性原子による光格子時計に大き く分けることが出来る。イオン時計については80年代よ り欧米の研究所を中心に開発が進められてきたが, 光格 子時計については東大の香取教授が提案・開発した日本 発の技術であり，本稿の筆者の一人である井戸も開発初 期のストロンチウム原子のレーザー冷却実験において苦 楽を共にし，また米国にて光格子時計の普及を図ったた けに親近感を抱くところではある。しかし，最も分かり やすい時計の性能を表す指標である確度については現時 点でNISTが開発している $\mathrm{Al}^{+} や \mathrm{Hg}^{+}$の単一イオン時計に 及ばない，このような現実を踏まえ，現在NICTではSr 光格子時計 $\cdot \mathrm{Ca}^{+}$単一イオン時計双方の開発を進めてお り, 単一イオン時計についてはより将来性の高い $\operatorname{In}^{+} に$ よる時計に徐々にシフトしていく予定である。単一イオ ン時計については松原による別稿を参照頂くとして, こ こでは光格子時計についてその実験的な詳細及びNICT での開発状況を報告し, また光格子方式・単一イオン方 式を問わず, 現在の光周波数標準開発におけるボトル ネックとなっているクロックレーザーを安定化するため の光共振器についてNICTで開発されつつある新型共振 器の設計を紹介する.

\section{Sr光格子時計ーNICTでの開発の状況一}

ストロンチウム $(\mathrm{Sr})$ 原子を使った光周波数標準は, 遷 移の自然幅が約 $10 \mathrm{mHz}$ と極めて狭い ${ }^{1} \mathrm{~S}_{0}{ }^{3}{ }^{3} \mathrm{P}_{0}$ 遷移の, 無摂 動状態での遷移周波数を利用する。この遷移 $\mathrm{S}_{0}{ }^{-}{ }^{3} \mathrm{P}_{0}$ (時 計遷移と呼ばれる. Fig. 1参照.) は本来禁制遷移である が, フェルミオン同位体 ${ }^{87} \mathrm{Sr}$ は核スピン $(I=9 / 2)$ を持つ ため超微細結合が生まれ, 非常に弱くではあるが遷移が 可能になっている1).

$\mathrm{Sr}$ 原子の時計遷移に対する魔法波長は, およそ813 nm であることが実験的に確かめられている ${ }^{2}$. 本実験でも この波長のレーザーを使って光格子ポテンシャルを作 り, そこにトラップされた ${ }^{87} \mathrm{Sr}$ 原子の時計遷移を分光し ている. 光格子ポテンシャルのポテンシャル深さは, 温 度にして30 $\mu \mathrm{K}$ 程度である。したがって，光格子ポテン

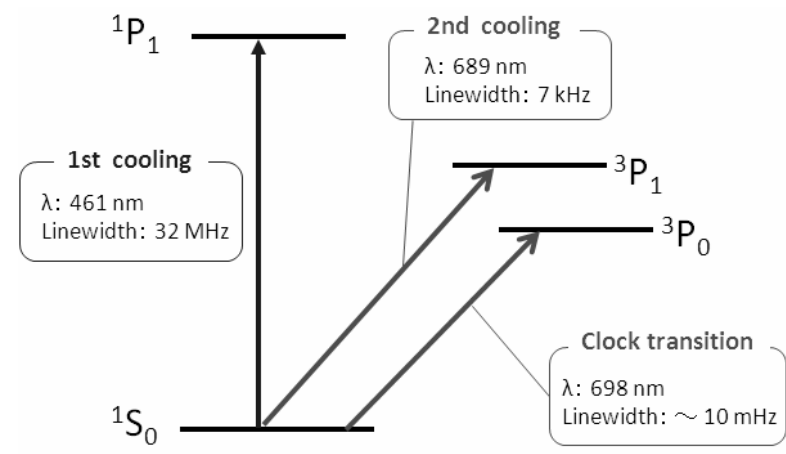

Fig. 1 Relevant energy level diagram of strontium atoms.
シャルにSr原子をトラップするためには，ポテンシャル 深さよりも十分低い温度までSr原子を冷却する必要があ る.

Sr原子は常温での飽和蒸気圧が低いため，まずは温度 $600{ }^{\circ} \mathrm{C}$ 程度のオーブンで $\mathrm{Sr}$ 蒸気を生成し，原子ビームを 生成する。次に, この原子ビームに対向する方向から, 強い遷移 ${ }^{1} \mathrm{~S}_{0}{ }^{1}{ }^{1} \mathrm{P}_{1}$ (Fig. 1参照)に共鳴したレーザーを照射 し，その強い輻射力により原子ビームを減速する。この 際，周波数を共鳴から $800 \mathrm{MHz}$ ほと負に離調して自由空 間に打けるドップラーシフト分を補正する。加えて, オーブンからトラップチャンバーまで空間的に磁場に勾 配をつけることで, 減速に伴うドップラーシフトの変化 をゼーマンシフトで補い, 原子に対して常にレーザーが 共鳴するようにしている(ゼーマン減速法 $)^{3)}$.

こうして減速された原子は, トラップチャンバーの中 心に到達し，そこに用意された磁気光学トラップ (MOT)に捕獲される ${ }^{4)}$. MOTとは, アンチヘルムホルツ コイルが生成する磁場勾配中で原子に対して6方向から レーザー光を照射することで，原子を冷却しつつ磁場の 零点に空間的にトラップする手法である。本実験では, 最初に強い遷移 ${ }^{1} \mathrm{~S}_{0}{ }^{-} \mathrm{P}_{1}$ （自然幅 $32 \mathrm{MHz}$ ）を用いたMOTに 原子をトラップしている。強い遷移を用いたMOTでは, 到達可能温度は $2 \mathrm{mK}$ 程度で $10^{6}$ 個程度の原子を捕獲する ことが可能である。これらの原子をさらに冷却するた め, 冷却遷移を到達可能温度のより低い, 弱い遷移 ${ }^{1} \mathrm{~S}_{0^{-}}$ ${ }^{3} \mathrm{P}_{1}$ に切り替えて再捕獲する ${ }^{5)}$ 。これにより, 原子は $2 \mu \mathrm{K}$ 程度にまで冷却され, 深さ $30 \mu \mathrm{K}$ 程度の光格子ポテン シャルで原子を捕獲することが可能となる，以上の手順 により，我々はおよそ $10^{4}$ 個の ${ }^{87} \mathrm{Sr}$ 原子を一次元光格子ポ テンシャルに捕獲している.

一方, 線幅の極めて狭い時計遷移の周波数を精密に測 定するためには, 時計遷移励起用のレーザー(クロック レーザー)の周波数を可能な限り安定にする必要があ る. $\mathrm{Sr}$ 原子の場合, 時計遷移の波長は698 nmである。こ の波長は半導体レーザーで安価に直接出すことが可能で あり, 高い周波数安定度については半導体レーザーの周 波数を高フィネス $(F \sim 300,000)$ の外部共振器に安定化し て実現している。この外部共振器は, 空気ゆらぎ, およ び床からの振動によるミラー間隔の不安定性を取り除く ため, 真空槽内に入れられた上で, 精密除振台 (共振周 波数 $0.5 \mathrm{~Hz}$ ) に設置されている. さらに, 共振器のミ ラー間隔を決めているスペーサーには超低熱膨張ガラス を用い，その温度ゆらぎを $\pm 500 \mu \mathrm{K}$ 以下に精密にコント ロールし, 長期の周波数安定度も向上させている.

Fig. 2に本実験のクロックレーザー $(698 \mathrm{~nm})$ と冷却サ ファイア発振器 (Cryogenic sapphire oscillator, CSO) との 周波数安定度を比較した結果を示す.クロックレーザー の周波数安定度は，ある測定時間 $\tau$ に対する安定度を表 すAllan deviationと呼ばれる指標を用いて評価されるこ とが一般的である. Fig. 2では横軸が平均化時間 $\tau$, 縦軸 がAllan deviationである. CSOとはサファイア結晶内の whispering gallery modeを利用した発振器で, 結晶を $10 \mathrm{~K}$ 以下の低温に置くことによってマイクロ波域での究極の 


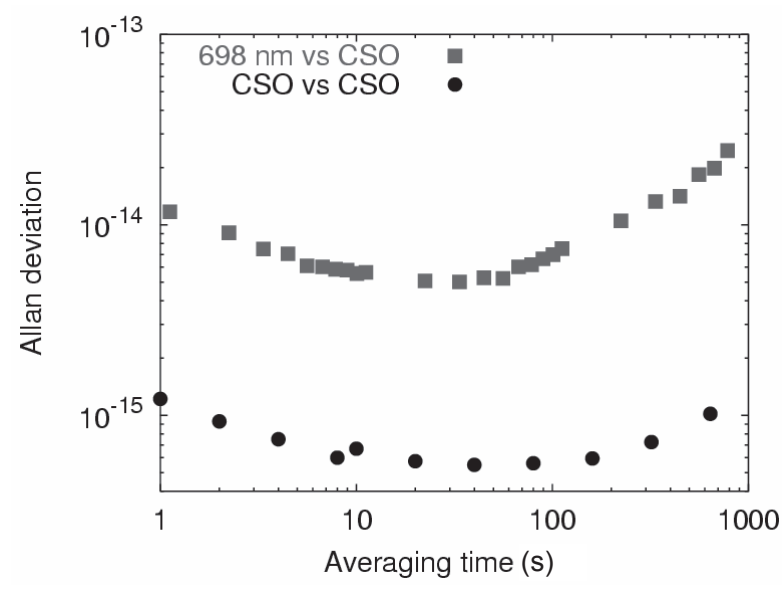

Fig. 2 Instability of the $698 \mathrm{~nm}$ clock laser obtained by the comparison against a cryogenic sapphire oscillator.

周波数安定度を実現しており, 図中の丸点のデータが CSO自身の安定度を表す。観測された我々のクロック レーザーの安定度(図中, 四角) は, CSO自身の安定度よ りも十分大きいことを考えると, クロックレーザー自身 の安定度を表しているといえる。クロックレーザーの安

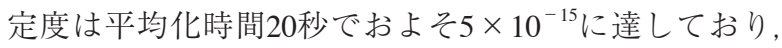
現在の安定度でも Hzレベルでの時計遷移の周波数測定 は可能である。しかし, クロックレーザーの安定度の限 界を決めると考えられているミラーの熱雑音・共振器の 機械振動に起因する安定度のレベルは $10^{-16}$ 台後半であ ると予測され, さらなる安定度の向上を目指し, 現在も 装置の改良を行っている。

以上で, 一次元光格子ポテンシャルにトラップされた ${ }^{87} \mathrm{Sr}$ 原子，およびその時計遷移を観測するための安定な クロックレーザーがそろった。以下では, ${ }^{87} \mathrm{Sr}$ 原子の時 計遷移 ${ }^{1} \mathrm{~S}_{0}{ }^{3} \mathrm{P}_{0}$ の分光実験の結果を述べる。実験では，ク ロックレーザーを光格子ポテンシャルにトラップされた ${ }^{87} \mathrm{Sr}$ 原子に照射した後, 強い遷移 $\mathrm{S}_{0}{ }^{-} \mathrm{P}_{1}$ に共鳴したレー ザーを照射し原子からの発光を観測した。 クロックレー ザーが時計遷移に共鳴すると, 原子は励起状態 ${ }^{3} \mathrm{P}_{0}$ に励 起されその準位にとどまるため, 強い遷移に共鳴した レーザーを吸収しなくなり発光も観測されなくなる。す なわち, 本実験では時計遷移の励起は発光の減少として 観測される。

Fig. 3が本実験で観測された時計遷移のスペクトルで ある。横軸はクロックレーザーの周波数(観測された共 鳴の中心を0としている), 縦軸は原子からの発光強度で ある。観測されたスペクトル線幅は $1.2 \mathrm{kHz} ゙$ むった。 これは残留磁場により, 基底状態および励起状態の超微 細構造がゼーマン分裂を起こした結果であると考えてい る。このスペクトルを取るのと同時に, TAI(国際原子 時)にリンクされた光周波数コムを使い, その時のク ロックレーザーの絶対周波数を測定した。そして，この 時計遷移の絶対周波数測定を繰り返した結果, 共鳴周波 数は429 228004229.80 (12) kHzと測定された。 この值 は, 2009年の国際度量衡委員会 (CIPM)の勧告值と工 ラーの範囲内で一致している。

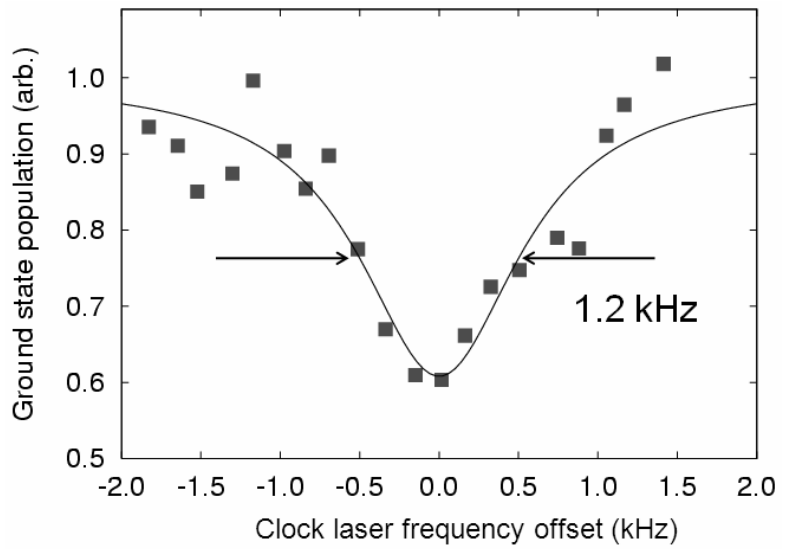

Fig. 3 Observed spectrum of the ${ }^{87} \mathrm{Sr}$ lattice clock transition.

NICTにおいて実現した ${ }^{87} \mathrm{Sr}$ 光格子時計については, 2006年の秒の二次表現としての採択に貢献した東大一 $\operatorname{AIST}$ 連合・JILA (米)・SYRTE(仏)につぐ, 4つめの研究 機関となるが, この他にもSrについては独伊英中加ポー ランド，Ybについては米日中独等多数の国立標準研究 所・大学で研究が精力的になされている。では上述した ように確度が未だNISTの $\mathrm{Hg}^{+} や \mathrm{Al}^{+}$イオン時計に及ばな いにもかかわらず, なぜ現在多数の標準研究所が光格子 時計の開発を行っているか, その最大の理由は光格子時 計が潜在的に備えている優れた短期安定度にある。一般 に原子時計の安定度は, 原理的にはクロックレーザーの 照射後に基底状態・励起状態間のポピュレーションの比 率を破壊測定する際に生じる量子ノイズ(量子射影ノイ ズ)によって制限され，これは

$$
\sigma(\tau)=\frac{\Delta v}{v} \sqrt{\frac{T}{N \tau}}
$$

で表される。尚, ここで $\Delta v / v$ は高分解能分光を行う際の $\mathrm{Q}$ 值，Tは計測1回に要する時間，Nは原子数である. 従って高分解能分光のスペクトル形状が同一であれば多 数の中性原子 $\left(10^{4}-10^{5}\right.$ 個 $)$ を利用する光格子時計はイオ ン時計に比べて安定度の観点からは圧倒的に有利なこと が分かる。、イクロ波領域ではこれまで確度を求めるな らばCs, 短期安定度を求めるなら水素メーザーもしく はCSOが使われており，13桁以上の精度を狙う研究開発 の現場ではより位相雑音が小さい水素メーザーの方が周 波数コムや信号発生器等の基準信号としては使い勝手が よく, 実際に大学等通常の研究環境においては水素メー ザーの基準周波数の供給を受けられないことが周波数標 準の研究の遂行を困難にしているといっても過言ではな い. これとのアナロジーを考えると, 万一今後の確度向 上について原理的限界が光格子時計において見えてきた としても, 光格子時計は現行のメーザーもしくはCSOの 代替を光領域においてより優れた安定度で供給する手段 となるため, 光周波数標準の開発を進める上で必須の技 術なのである。 


\section{3. 光周波数標準開発の鍵を握る高安定光共振器の開発}

(1)式から分かるように，安定度を決めるもう一つの 重要なファクターは高分解能分光の $Q$ 值であり, これに ついては現在光格子時計・イオン時計双方ともクロック レーザーの線幅という技術的要因で制限されている。 ロックレーザーは通常高フィネス光共振器に安定化して 高域の位相雑音を抑圧したものを利用するが，この場合 光源の周波数安定度は光共振器にどれだけ完全にロック 出来るかではなく，レファレンスである光共振器の共振 器長そのものをどれだけ安定に保てるかで決まる。共振 器長の安定度については, 近年の誘電体多層膜の低損失 化技術の進歩により小型の共振器 (共振器長 $10 \mathrm{~cm}$ ) が与 える $1.5 \mathrm{GHz}$ という比較的大きなフリースペクトラルレ ンジ(Free Spectral Range, FSR)でも十分狭い共鳴線幅が 得られるようになり, さらに除振台及び共振器の支持方 法を工夫して外部からの振動に対する共振器長変化の感 度を低くすれば，鏡のブラウン運動による制限(熱杂隹音 リミット $\left.{ }^{6}\right)$ まで安定度が出ることが分かってきた。そ してさらにこの熱雑音リミットを押し下げるためには, 一般に，1)低温に冷やす2)共振器長を長くして共振器長 に対する熱雑音による鏡振動の影響を相対的に小さくす るの2種類のアプローチがある。この問題に関して我々 は2）の戦略を取り, 共振器長 $30 \mathrm{~cm}$ の新しい形状をした 光共振器を最近設計した。一般に共振器長が大きくなる と, 振動感受率が大きくなるため, 本設計では振動対策 が最も重要なポイントになる。

今回設計した $30 \mathrm{~cm}$ 長光共振器の形状をFig. 4に示す. 材質は，旭硝子(株)製の低熱膨張ガラスである $\mathrm{AZ}^{7}$ を使 う予定である。これはヤング率 $68 \mathrm{GPa}$, ポアソン比 0.17 , 密度 $2.2 \mathrm{~g} / \mathrm{cm}^{3}$ で室温付近にゼロ膨張温度を持って おり，熱膨張係数などULEとほぼ同一性質のガラス材で ある. ULEの場合, $30 \mathrm{~cm}$ という比較的大型のサイズで,
なおかつ精密な切削加工をしたものを調達するのは困難 であったためここではAZガラスを使用しており，ULE に対する性能面での明らかな優位性があるわけではな い. 共振器の本体部分は直方体をしており，長いために 横置きにする。全体のサイズは長さ $30 \mathrm{~cm}$ 幅 $8 \mathrm{~cm}$ 高さ $9 \mathrm{~cm}$ で，固定のための脚は本体と一体型とし，直方体の ガラス材に横穴を開けることによって本体・支持脚・台 座部分を形成するようにした。本体部分の高さは $5 \mathrm{~cm}$ で，中心にレーザー光を通すための孔 $(\phi 12)$ が開いてい る。脚の下部は共振器を支える台座で, 底面から伝わる 振動についてその空間分布の非一様性を緩和することを 期待している。 また，この下部の台座部分と脚部分に は, 重力や振動の加速度によって共振器本体部分に掛 かった応力を逃がし本体の歪みを軽減する効果も持たせ てある。一般に共振器は筐体の対称軸に光軸を置いて対 称性により振動感度を抑えるのが基本戦略であるが，こ のデザインでは鉛直 $(\mathrm{Y})$ 方向への対称面がないため鉛直 方向の加速度感度を抑制することが最も重要であり，そ のための具体的に重要なパラメータは支持脚の位置と幅 になる，底面から上向きの加速度が掛かった場合，まず 鉛直方向に共振器は潰れ, その際にポアソン比のために 鏡は外に押し出される。一方, この構造では共振器の脚 で支えられていない部分は慣性により下方に垂れ下が り，その際，鏡は光軸方向にもわずかにシフトする効果

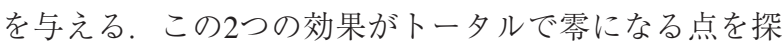
せば共振器長の垂直方向の振動感度を抑制することが可 能である。

設計は有限要素法を用いて行った，有限要素法は，個 体を小さな領域(要素)に分解し，それぞれの接点にかか る応力と変位を計算するものである。ポワソン比やヤン グ率，密度など材料固有の物性值を使うことによって例 えば重力によるたわみなど，実際に材料が受ける変形の 様子を計算することが出来る，通常の機械設計等の場合
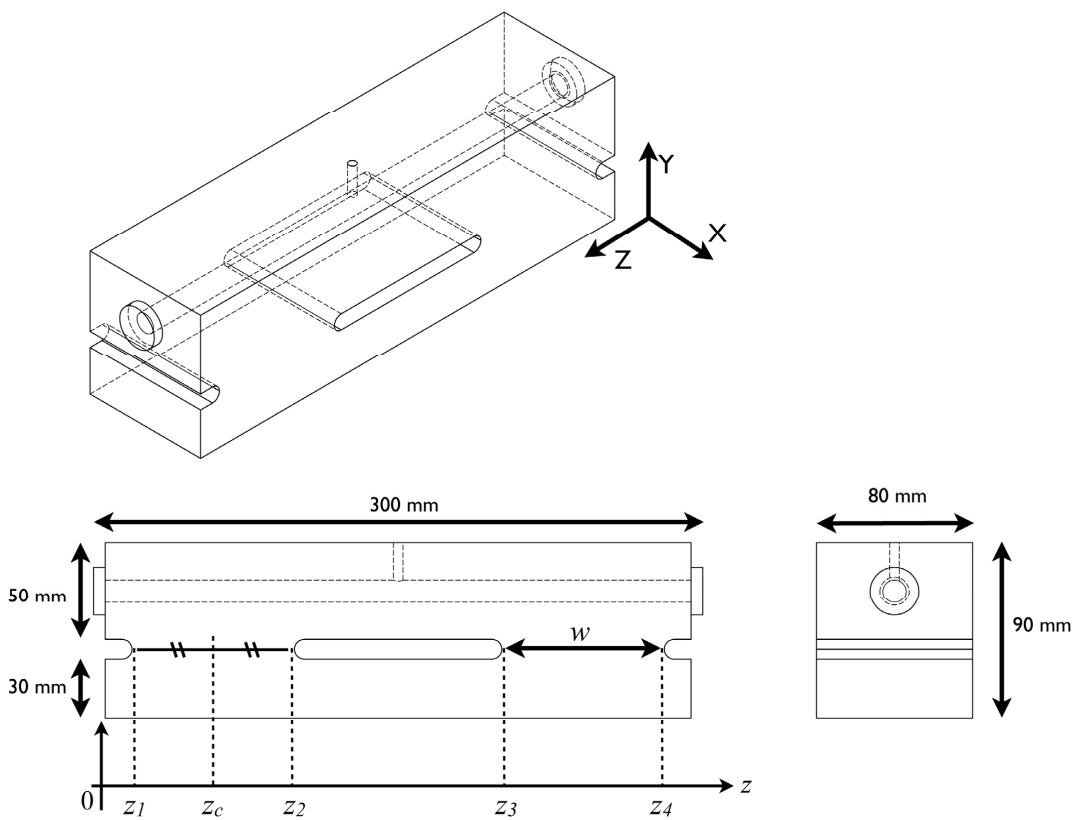

Fig. 4 The design of vibration insensitive cavity with 30 -cm-length. 
の有限要素法では, 力がかかる部位とその大きさ, そし て境界条件として動かない拘束部位を仮定することに よって計算が成される。一方, 光共振器の場合, 想定す る力は外部との接触点 (この場合底面)から伝わり, 他の 部分は外的な拘束は無い. この場合のシミュレーション を有限要素法に落とし込むためには慣性力の概念を利用 するのが有効である. 共振器の外部接触点が振動によっ て運動するが，この外部接触点と共に運動をする座標系 から見ると, 接触点以外全体に振動による加速度が逆向 きに掛かっているように見える，従って支持部が動かな いと仮定して, 他の部分に拘束を掛けずに一様に加速度 がかかると考え, 変形を考えれば良い。 この状態は加速 度が鉛直上方向であれば単に接触点を拘束した上で系に 重力を掛けていることと相似形である. 有限要素法を用 いて低振動感度の光共振器を設計する試みは幾つか例が あり, 従来の円筒型以外の形状でより振動感度の低い光 共振器の開発がなされている ${ }^{8-10)}$. さて, 形状の最適化 のプロセスとしてはまず最初に共振器の底面全体を固定 とした上で加速度は鉛直方向(図の $-Y$ 方向)に $1 \mathrm{~m} / \mathrm{s}^{2}$ を かけて, ミラー中心点のZ方向変位 $(\Delta z)$ がどのくらいに なるのか計算した，支持脚の中心の位置 $z_{\mathrm{c}}$ を縦軸，その 幅 $w$ を横軸として $\Delta z$ の依存性を示したのがFig. 5であ る。図中の黑線が, 加速度による共振器長の変位がゼロ となる $z_{c}$ と $w$ の組み合わせである。この等高線上であれ ばどの組み合わせでも鉛直方向の加速度については感度 ゼロであるので, 黒線上の14点 $(\mathrm{A} \sim \mathrm{N})$ を取り上げてこ の中でその他の条件について計算し, 最適解を探すこと にした。

まず，鉛直方向に加速度が掛かった場合のミラーの角 度変化を計算した。Fig. 5のAからNまで14個の点での角 度変化 $\theta_{\mathrm{y}}$ は〜 $10^{-9} \mathrm{rad}$ で, E，Fのあたりで角度ゼロとな る。 ミラーの角度が共振器長に与える変化は原理的には 〜 $l \theta^{2}$ でスケールされる二次の効果であり，無視でき る。しかしながらこれは共振器の機械的な対称軸と共振 器内の光軸が完全に一致している条件下であり, そうで ない場合ミラーの中心の光軸孔の中心からのずれを $d$ と

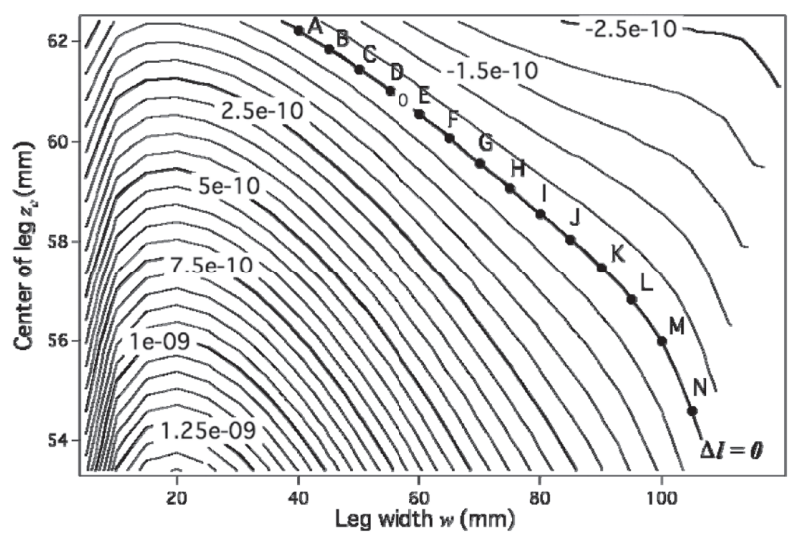

Fig. 5 Contour plot of the fractional sensitivity of the cavity length to vertical unit acceleration. The unit is $/ \mathrm{ms}^{-2}$. The sensitivity is depicted as a function of the position and width of monolithic supports produced by making slots beneath the cavity.
すると共振器長変化は $d \cdot \theta_{\mathrm{y}}$ となる， $d$ については基本的 には鏡をオプティカルコンタクトをする際の位置決め精 度で決まり，これを $0.5 \mathrm{~mm}$ と仮定すると $10^{-12} / \mathrm{ms}^{-2}$ 程度 となった。

次に共振器の水平方向の加速度に対する感度について 検討を行った。尚, 通常の実験室では地面振動について 鉛直方向と水平方向でほぼ同程度の大きさを持つことが 分かっている. 水平の二方向について変形の様子を表し たのがFig. 6である。図のa)がx方向，b）がz方向に $1 \mathrm{~m} / \mathrm{s}^{2}$ の加速度がかかった場合の共振器のz方向変位の様子を 実際の表示したものであり，それぞれの変位は濃淡に よって示してある。まずa)についてだが，共振器の中央 部分から左右対称に変位が起こるため, 光軸が共振器の 機械的中心軸と完全に一致している場合ミラーの中心の 光軸方向へのシフトについては加速度感度は非常に小さ い.オプティカルコンタクトのずれに起因する光軸と機 械的中心軸のずれを $d=0.5 \mathrm{~mm}$ であるとした場合, $\mathrm{A}$ か らNまでの14点での加速度感度は $10^{-12} / \mathrm{ms}^{-2}$ のオーダー に収まった。これは鉛直方向加速度によるミラーの傾き から来る振動感度とほぼ同程度で, $30 \mathrm{~cm}$ と言う長い共 振器を横向きに保持しているにもかかわらず比較的小さ く, 支持部分を大きくして共振器本体への応力を脚及び ベースプレートに逃がしている効果が出ている. Fig. 6 の（b）を見ると，光軸孔に平行な方向に加速度が掛かっ た場合の共振器の変位は，二枚のミラーで同じ方向であ ることがわかる。この二枚のミラーの中心での変位と傾 き角を詳しく調べるとこの二つはちょうど相殺されるた め, z方向加速度の影響については無視しても良いこと がわかった。

また工作精度が共振器の加速度感度にどう影響を与え るかについても調べた。 ここで問題としている振動感度 への影響が一番大きいのは, Fig. 4の $z_{1} \sim z_{4}$ のパラメー夕 である。旭硝子によると，この形状のAZガラスの工作

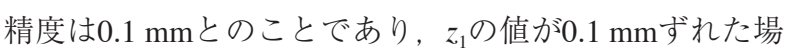
合振動感度は $10^{-13} / \mathrm{ms}^{-2}$ 程度変化することが分かり，工 作精度が性能を致命的に制限することはないようであ る。 また, 有限要素法によると共振器の持つ最低固有振 動数はおよそ5 kHzであった。精密除振台上では0.5$1 \mathrm{~Hz}$ 程度をカットオフ周波数として高域の振動が除振さ れるため, このシミュレーションのような静加速度によ る振動感度の見積りで十分である.
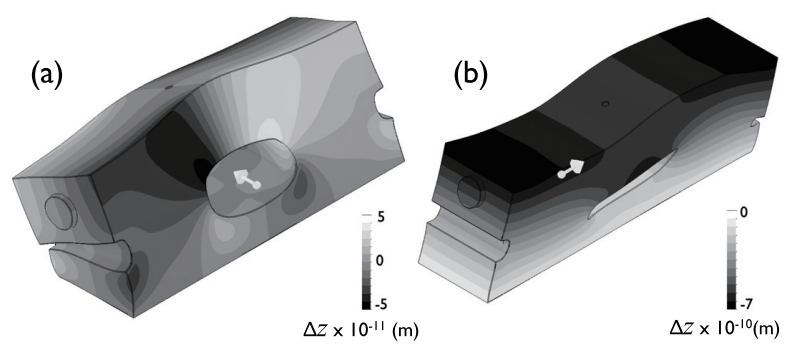

Fig. 6 Strain of cavity induced by horizontal accelerations oriented to (a) transverse and (b) longitudinal directions against the optical axis. 


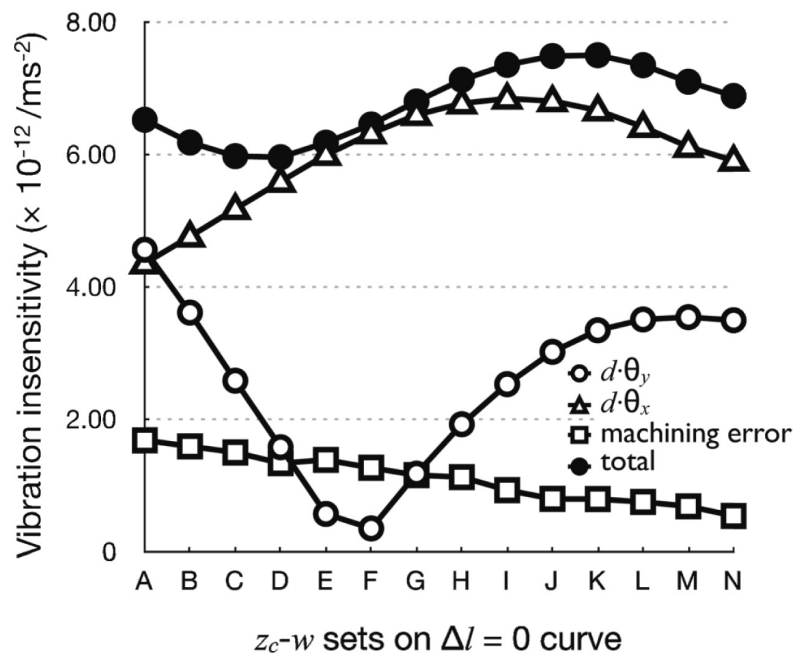

Fig. 7 Summary of the vibration sensitivity of the cavity length. Total fractional sensitivity of $\sim 10^{-12} / \mathrm{ms}^{-2}$ is in same level with state-of-the-art vibration insensitive $10 \mathrm{~cm}$ cavities.

Fig. 7が全ての計算結果のまとめである. $y$ 方向加速度 による角度変化と $x$ 方向加速度による角度変化, 工作精 度の各変化に対する振動感度とそれらをまとめた全振動 感度をプロットしてある。 今回設計した共振器の振動感 度は6 $\times 10^{-12} / \mathrm{ms}^{-2}$ 程度で，レーザーの波長が $698 \mathrm{~nm}$ の 場合 $2.5 \mathrm{kHz} / \mathrm{ms}^{-2}$ に相当する。これは現在一般的に用い られている長さ $10 \mathrm{~cm}$ の共振器で振動対策を施したも の ${ }^{10)}$ と同レベルにある。共振器長を $30 \mathrm{~cm}$ にするとに よって熱杂隹音は $3 \times 10^{-16}$ のレベルまで抑えることが出来 るが, 本設計によって一般の地面振動 + 受動精密除振 台の環境 (帯域 $>0.5 \mathrm{~Hz}$ で〜 $10^{-4} \mathrm{~m} / \mathrm{s}^{2}$ ) で振動による制限 を熱雑音と同程度に抑えられていることが分かる. Fig. 7ではオプティカルコンタクトの空間的なずれdについ て, 鉛直方向, 水平方向, 共に $0.5 \mathrm{~mm}$ と仮定してい る.この場合 $\mathrm{A} \sim \mathrm{N}$ までの14点で比較的フラットな依存 性を示す $y$ 方向振動感度が支配的であり，A〜Nの中で最 適な組み合わせは特に見つからなかった。 その上で，定 常的な重力による経年変化の影響が少なくなるようには おそらく太い脚の方が望ましいと考えられる. 但し, 技 術的な要因で $x$ 方向のオプティカルコンタクトの位置の 公差を非常に小さく出来る場合はE or Fが最適となる. 尚, 本設計の共振器は現在製作中で, いずれ実験結果を 報告する予定である。

\section{4. まとめと展望}

以上，NICTにおいて筆者らが開発しているSr光格子 時計及び新型光共振器について概略を述べた．Sr光格子 時計については残留磁場等スペクトルを広げている要因 を取り除き，相互作用時間でリミットされる線幅を実現 し，さらに時計遷移分光の結果を直接クロックレーザー 周波数にフィードバックして，長期の積算によって時計
精度を向上させ，最終的に系統誤差を16桁もしくはそれ 以上まで縮小させ，その限界を探る予定である。また， 光共振器については上述したように現在製作中である が, ここでは零膨張ガラス材やイオンビームスパッタリ ングによって得られる低損失誘電体多層膜を国内企業か ら調達する予定で，これまで完全に米国Advanced Thin Films社に依存していた光共振器の作成に関してそれと 比肩しうる技術を国内に確立すべく研究開発型独立行政 法人として努力しているところである.

NICTにおける光原子時計はその完成した暁には国際 原子時及び日本標準時に貢献することが求められるが, Sr光格子時計や単一イオン時計を24時間 365 日動作させ て日本標準時を供給するのは非現実的である。この状況 は現在のCs原子泉時計も同様であり，Cs原子泉時計 ${ }^{11}$ に おいてもノンストップでの連続運転の実現は非常に困難 であり，通常間欠的に運転して国際原子時の較正に使用 されている. 従って, 現行のCs原子時計の代替として $\mathrm{Sr}$ 光格子時計によって国際原子時や日本標準時の較正に使 用するということが光原子時計による時刻供給への貢献 としては最初のステップと思われる。では較正される日 本標準時は現在どのようにして生成されているのか？こ れは誤解をおそれず簡単に言うと, 多数の商用Cs時計 のアンサンブルの信号で計算上の安定な標準時を作り出 し，これに短期安定度に優れた水素メーザーの周波数を 長期的に追随させて生成している。時刻の途切れない安 定な供給という観点に立ったとき，現在の商用Cs原子 時計 (SymmetriCom社 5071A等) を多数運転することに よって得られるロバストネスと午長性は偉大である。光 原子時計が精度の面で従来の原子時計を凌駕することが 確認された今, その精度を複数の光原子時計の相互比較 によってさらに上げると同時に，商用マイクロ波時計と 比肩しうる安定性と圥長性を光領域の時計において実現 することもまた時刻に責任を持つ標準研究所としての大 きな目標であるが, 現状としてはまだ有力な方式は出て きていない。 また同時に時刻の供給について光原子時計 によって得られる時刻周波数情報を性能劣化を伴わずに 物理的に離れた地点に届ける技術の確立をする必要があ る。これについてNICTは最近ダークファイバによる東 大との光ファイバリンクを確立して東大-NICT間での高 精度周波数配信技術の研究開発を始めたところであ $り^{\dagger}$, ここでの配信技術の評価手段は東大と NICTの $\mathrm{Sr}$ 原 子時計の周波数比較そのものである. ロバストな光原子 時計群とその高精度配信技術，これら双方が成し遂げら れたとき，ついに我々は時をも光によってより正確に刻 むことが出来るようになるのである.

本稿の実験について長野 重夫博士，志賀 信泰博士， 石島 博氏, 小山 泰弘博士, 細川 瑞彦博士の協力に感謝 致します。また，クロックレーザーの安定度測定につい ては, 熊谷基弘博士(NICT), C. R. Locke博士, J. G. Hartnett博士(西オーストラリア大), G. Santarelli博士 (フ ランスSYRTE研究所)によるCSO発振器の開発・運用な

†このファイバリンクにおいては量子鍵配信のフィールドテストも行われる予定である. 
くしては不可能なものであり,ここに深く感謝いたしま す.

\section{参考文献}

1) S. G. Porsev and A. Derevianko: Phys. Rev. A 69 (2004) 042506.

2) M. Takamoto, F-L Hong, R. Higashi, and H. Katori: Nature 435 (2005) 321; A. D. Ludlow, M. M. Boyd, T. Zelevinsky, S. M. Foreman, S. Blatt, M. Notcutt, T. Ido, and J. Ye: Phys. Rev. Lett. 96 (2006) 033003; A. Brusch, R. L. Targat, X. Baillard, M. Fauche, and P. Lemonde: Phys. Rev. Lett. 96 (2006) 103003.

3) W. Phillips and H. Metcalf: Phys. Rev. Lett. 48 (1982) 596

4) T. Kurosu and F. Shimizu: Jpn. J. Appl. Phys. 29 (1990) L2127.
5) H. Katori, T. Ido, Y. Isoya, and M. Kuwata-Gonnokami: Phys. Rev. Lett. 82 (1999) 1116.

6) K. Numata, A. Kemery, and J. Camp: Phys. Rev. Lett. 93 (2004) 250602.

7) Private communications, Asahi Glass Co. Ltd.

8) L. Chen, J. L. Hall, J. Ye, T. Yang, E. Zang, and T. Li: Phys. Rev. A 74 (2006) 053801.

9) S. A. Webster, M. Oxborrow, and P. Gill, "Vibration insensitive optical cavity," Phys. Rev. A 75 (2007) 11801(R).

10) J. Millo, D. V. Magalhães, C. Mandache, Y. Le Coq, E. M. L. English, P. G. Westergaard, J. Lodewyck, S. Bize, P. Lemonde, and G. Santarelli: Phys. Rev. A 79 (2009) 053829.

11) M. Kumagai, H. Ito, M. Kajita, and M. Hosokawa: Metrologia 45 (2008) 139. 時計遷移(clock transition)

周波数標準はまず周波数可変の発振源を用意し, その 発振周波数を原子や分子の2状態間の量子遷移に共鳴す るよう制御することによって実現する.この原子分子等 の量子遷移を時計遷移と言い, 周波数の低い方から超微 細構造間のマイクロ波遷移 · 分子の振動回転遷移 · 原子 の電子遷移等が利用される. これらの遷移が周波数標準
として機能するためには，自然幅が狭く，なおかつ外 場・周辺温度等の環境条件による周波数のシフトが小さ いことが要請され, 光学遷移では一般に線幅が狭い異重 項間の双極子遷移や多重極遷移が利用される.

(井戸 哲也) 